\title{
Dolomitization and silicification in low-energy lacustrine carbonates (Paleogene, Madrid Basin, Spain)
}

\author{
M.A. Bustillo ${ }^{\mathrm{a}, *}$, M.E. Arribas ${ }^{\mathrm{b}}$, M. Bustillo ${ }^{\mathrm{b}}$ \\ ${ }^{a}$ Dpto. de Geología, Museo Nacional de Ciencias Naturales, CSIC, José Gutiérrez Abascal 2, Madrid 28006, Spain \\ ${ }^{\mathrm{b}}$ Dpto. de Petrología y Geoquímica, Facultad de Ciencias Geológicas, Universidad Complutense, Madrid 28040, Spain
}

\begin{abstract}
Repetitive sequences of carbonate deposits, occurrence include in the lower part of the Paleogene Carbonate Unit (northeast border of the Madrid Basin), have been studied, defining regressive lacustrine sequences and early diagenetic processes. Binocular microscopic examination, scanning electron microscopic/energy dispersive X-ray observations, and X-ray diffraction analyses joint to isotopic studies $\left(\delta^{18} \mathrm{O}\right.$ and $\left.\delta^{13} \mathrm{C}\right)$ have been used to characterise the facies and environments. The sequences consist of a lower uncemented carbonate mud unit, calcitic or dolomitic in composition, and an upper carbonate unit (arenites, bioclastic limestones, and microbial laminated limestones with cherts). Visual features (vertical prismatic structures, fissures, massive nodulization, rhizoliths, brecciation) and microscopic features (micrite micronodules, vug porosity, circumgranular cementation, gypsum lenticular crystals) outline pedogenic processes. These features, found locally in bioclastic and microbial laminated limestones or in dolomite uncemented muds, define, respectively, palustrine limestones or dolocretes. Facies analysis allows us to define several lacustrine sub-environments (basinal, littoral, eulittoral and supralittoral) and characterises different types of shallowing upward lacustrine sequences, either with or without subaerial exposure. The isotopic values of the bioclastic and microbial laminated limestone (from $-5.77 \%$ to $-6.78 \%$ or $\delta^{13} \mathrm{C}$, and from $-5.25 \%$ to $-5.53 \%$ ofor $\delta^{18} \mathrm{O}$ ) and those of uncemented calcitic muds (from $-5.80 \%$ to $-7.01 \%$ for $\delta^{13} \mathrm{C}$, and from $-4.98 \%$ to $-5.58 \%$ or $\delta^{18} \mathrm{O}$ ) establish that both types of carbonates precipitated in equilibrium with meteoric waters. In the palustrine carbonate deposits, the $\delta^{13} \mathrm{C}$ values suggest a strong organic contribution. The dolomitization that only affected the uncemented carbonate muds is early interpreted because of the structural and compositional characteristics of the dolomite (micro-rhombic dolomicrite, nearly stoichiometric and poorly ordered), and because the calculated average $\Delta^{18} \mathrm{O}$ dol-cal for calcitic and dolomitic uncemented muds is about $6 \%$. The $\delta^{18} \mathrm{O}$ isotopic values indicate that the dolomite precipitated from water that was slightly more enriched in heavy isotopes than the calcite, because of an increase in evaporation rates. Nodules and nodular levels of cherts occur in the upper units of littoral and eulittoral sequences, probably as a consequence of the existence of microbial mats that could include the silica source. According to their mineralogy (Opal CT and quartz/moganite) and structures (double nodules, lamination and bioturbation), three types of chert are described (TB, MB and WO). These types define three general stages of silicification during the early diagenesis, from the recently buried to the postcompactation of carbonate deposits. The $\delta^{18} \mathrm{O}$ values of quartz show that the silicification and ageing of opaline phases occurred from meteoric waters, which were lighter than the calcite or
\end{abstract}

\footnotetext{
* Corresponding author. Fax: +34-91-564-4740.

E-mail addresses: abustillo@mncn.csic.es (M.A. Bustillo), earribas@eucmax.sim.ucm.es (M.E. Arribas), bustillo@eucmax.sim.ucm.es (M. Bustillo).
} 
dolomite precipitating waters. The cherts included in palustrine limestones show $\delta^{18} \bullet$ values of quartz that record more evaporated waters than those of the general stages of silicification.

Keywerds: Shallow lacustrine carbonates; Chalks; Dolomitization; Cherts; Paleogene; Madrid Basin

\section{Introduction}

In shallow and marginal lacustrine environments, relatively small changes in lake level can impact greatly on the depositional regimes. When such areas are

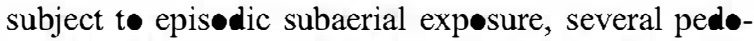
genic changes als• take place (Freytet and Plaziat, 1982). As a result, a great variation of facies, along with complex lateral and vertical changes, is frequent, making facies-sequence analysis very difficult and sømetimes impossible (Tucker and Wright, 1990; Platt and Wright, 1991). In low-energy lakes, carbonates are formed under intense biølogical activity, and in such cases, the meteoric and diagenetic transformations that the primary sediments suffer are both specific and considerable (Platt and Wright, 1991). Our study focuses $\bullet$ the different Paleøgene lacustrine carbønate sequences formed in shallow and marginal environments in low-energy lakes. The studied sequences are unusual in that they display uncemented carbonate muds together with indurated carbønates containing cherts.

Silicification is a significant diagenetic phenomenon of ancient carbonate rocks because the cherts, formed by it, shed light up॰n many aspects of the diagenetic history of the carbonate høst rocks. The silica concentration of the pore fluids, the chemical environment of the silicification, and the relative timing of the silicification with respect to the other diagenetic events that affect the carbønate host rocks can be ascertaine (Hesse, 1990).

The Paleøgene carbønate depøsits of the Madrid Basin are an interesting example of the above as they display sections with many, and successive, similar sequences. These repetitive sequences make it possible to study the local variations of carbonate sedimentation together with the different chert types and dolomitization. The purpose of this paper is: (i) to describe the sedimentary realms, analysing the palustrine and lacustrine carbonate facies and their asseciation in sequences, and (ii) to document the changes that the limestones underwent and to explain the formation of confined diagenetic facies that include dolomites and chert.

\section{Geological setting}

The Madrid Basin (Fig. 1A) is lecated in central Spain. It is a foreland basin formed during the compressive phase of the Alpine build-up, which als caused the formation of the Iberian Range and the Central System. The Central System is included in the Hesperian Massif hosting low to high-rank metamorphic rocks. The Iberian Range is a mountain belt with a double vergence and developed from a depositional trough of the aulacogen type filled with mesøzoic dep॰sits within the Iberian plate (Alvar• et al., 1979). The fill of the Madrid basin comprises Paleogene and Neøgene terrestrial depøsits. Paleøgene depøsits are scattered along the northeast border of the Madrid Basin (Fig. 1B) and are synoregenic with the Alpine -røgeny. Pale gene $\bullet$ utcrøps are nearest to the area $\bullet$ convergence between the Iberian Range and the Central System (Fig. 1A). In this area, the greater part of the Paleøgene depøsits consists of carbønate and detrital røcks, which $\bullet$ ccurs within a succession formed by tw॰ lithølogical units: Carbønate and Detrital Units (Arribas, 1986a,b, 1994) (Fig. 2). These units are apparently conformable above an evaporitic unit that is als possibly Paleogene in age. The sediments reflect an evolution from a lacustrine envirønment (Carbonate Unit) to one of the prograding alluvial fans (Detrital Unit) sourced from the Central System and Iberian Range (Arribas and Arribas, 1991). The base of this Paleøene succession is partially covered and erøded. The lower part of the succession contains a faunal ass $\bullet$ ciation $\bullet$ macr $\bullet$ and micr-mammals indicating a late Eøcene Headonian age (Arribas et al., 1983).

One of the best exposures of these Paleøgene sediments $\bullet c c u r s$ in the locality of Torremocha de Jadraque (Fig. 2B) (Guadalajara province). In this area, the 


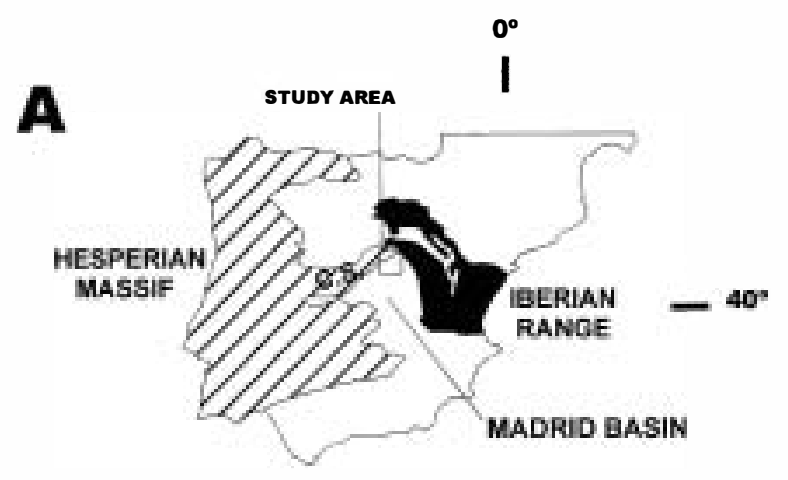

$\mathbf{B}$

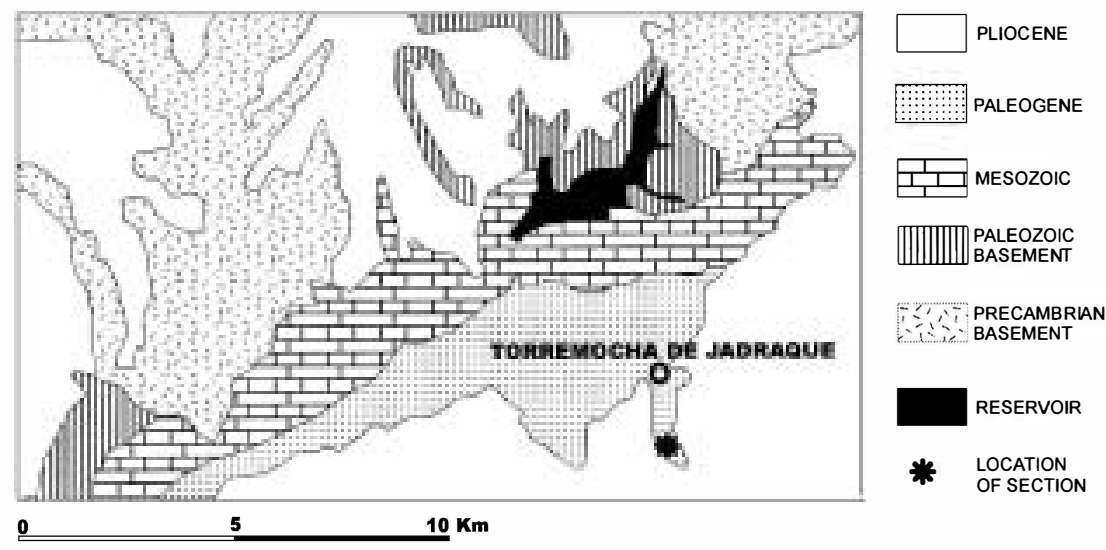

Fig. 1. Geological setting of the study area. (A) Distribution of the Hesperian massif, Iberian Range and Madrid Basin in the Iberian Peninsula. C.S., Central System. (B) Geological map of the study area and location of the studied stratigraphic section.

Paleogene succession has a maximum thickness of $880 \mathrm{~m}$. The carbonate unit, with a thickness of $510 \mathrm{~m}$, contains a variety of carbonate facies interpreted as deposits of a lacustrine environment (Arribas, 1986a). In this study, a section at the middle of the Torremocha de Jadraque exposure is analysed (Fig. 2). The studied section is formed by many sequences where uncemented carbonate (calcitic or dolomitic) muds are overlaid by limestones that frequently contain cherts. Along the Carbonate Unit, lacustrine sandstones also appear as sediments related to the alluvial fan progradation (Arribas, 1986b). The sandstones are mainly lithoarenites in composition (Arribas and Arribas, 1991), composed exclusively of carbonates (limestones and dolostones) derived from Mesozoic rocks of the Iberian Range.

\section{Sampling and analytical study}

The sampling strategy was to collect several samples from the sequences defined by an upper carbonate indurated unit and a lower soft unit (uncemented carbonate muds). The general mineralogy, the type of calcite, the proportion of $\mathrm{CaCO}_{3}$ to dolomite and the degree of ordering of the dolomite was determined by X-ray diffraction (Hardy and Tucker, 1988).

Textures and mineralogy were studied with a polarised light microscope and a scanning electron microscope (SEM, Philips KL-20) equipped with an energy dispersive X-ray analyser (EDAX-DX-4i). Trace-element determinations were made by ICPMS in the Chemical Laboratory of the University of Granada. After $\mathrm{HNO}_{3}+\mathrm{HF}$ digestion of $0.1000 \mathrm{~g}$ of 


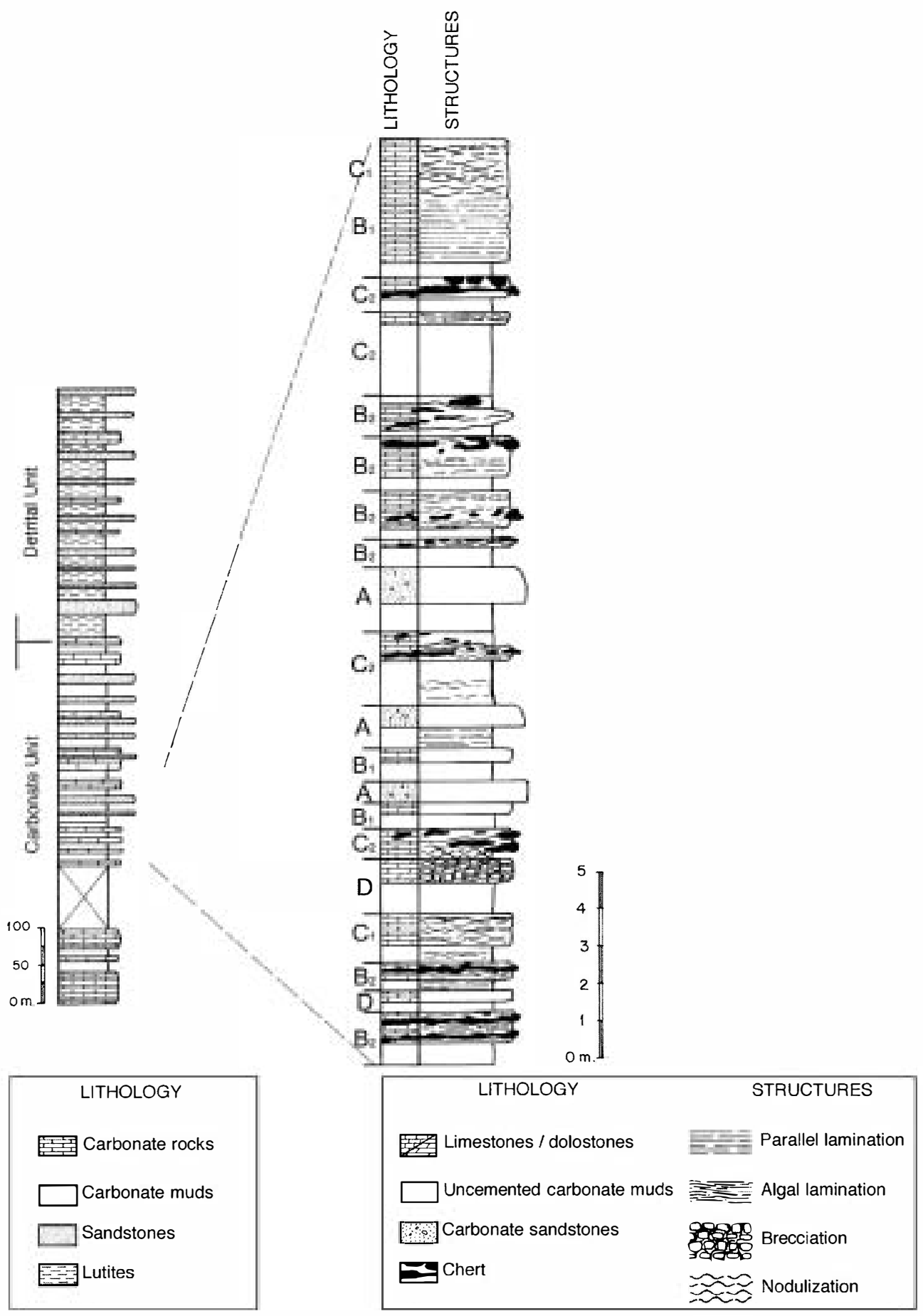

Fig. 2. Paleogene general section and studied section in the surroundings of Torremocha de Jadraque (A, B, etc., are the type of sequence of Fig. 8). 
sample pøwder in a Tefløn-lined vessel at $\sim 180{ }^{\circ} \mathrm{C}$ and $\sim 200$ p.s.i for $30 \mathrm{~min}$, evaporation to dryness, and subsequent dissølution in $100 \mathrm{ml}$ of $4 \mathrm{v} \bullet \%$ $\mathrm{HNO}_{3}$. Instrument measurements were carrie $\bullet$ ut in triplicate with a PE SCIEX ELAN-5000 spectrometer using $\mathrm{Rh}$ as internal standard. Precision was greater than $\pm 2 \%$ and $\pm 5 \%$ for concentrations of 50 and 5 ppm, respectively.

Is otope measurements were carried out in the Stable Isotope Laboratory at the University of Salamanca. Carbon dioxide was evolved from the carbønates using $103 \%$ phosphoric acid for $3 \mathrm{~h}$ (calcite) or $24 \mathrm{~h}$ (dolømite) in a thermostatic bath at $25^{\circ} \mathrm{C}$ (McCrea, 1950). Some calcites were analysed using an ISOCARB device at $90^{\circ} \mathrm{C}$. Oxygen from the cherts was extracted using the method of Clayton and Mayeda (1963), but empløying a løading technique as described by Friedman and Gleasen (1973) and $\mathrm{ClF}_{3}$ as reagent (Børthwick and Harmon, 1982). Isotopic ratios were measure in a Micromass SRA-II mass spectrometer. Overall precision, including extraction is $\pm 0.1 \%$ for $\delta^{13} \mathrm{C}$ and $\pm 0.06 \%$ for $\delta^{18}$ in carbonates, and $\pm 0.2 \%$ for fluorination. The values $\bullet$ btained for relevant standards are: for NBS- $19, \delta^{13} \mathrm{C}=2.00 \%$, $\delta^{18} \boldsymbol{0}=28.86 \%$, and for NBS-28, $\delta^{18}=9.6 \%$. Delta values take inte account corrections derived from the contribution of mass 17 to the $\delta^{18}$ values (Craig, 1957).

\section{Petrology and sedimentology}

\subsection{Carbonate facies}

\subsubsection{Tncemented carbonate muds}

These facies are porøus, massive carbønates and form the lower units in the sequences (Fig. 2). They constitute beds from 0.5 to $1 \mathrm{~m}$ thick, and high porosities are maintained in spite of the age and the depth of burial. They consist of calcite, dolømite or mixtures of bøth. Tw॰ types of facies have been defined: calcitic and dolomitic.

The calcitic muds contain more than $\mathbf{9 0 \%}$ calcite (LMC, with 2-4 m•l\% $\mathrm{MgCO}_{3}$ ). Under SEM, these muds are micrites comprising subhedral crystals, sømetimes with rhombic shapes, measuring up to $10 \mu \mathrm{m}$ and with a high intercrystalline porosity (Fig. 3a and b). Charophyte and ostraced fragments may be present in small proportions $(<2 \%)$. The calcitic muds display a low clay minerals content $(<10 \%)$. These clay particles are $\mathrm{Al}$-smectite, illite, palygorskite and sporadic sepiølite (Bustillø et al., 1998). Under thin section, pedogenic features, such as a circumgranular poresity

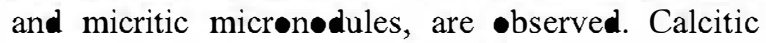
cementation $\bullet$ nly $\bullet$ ccurs løcally (Fig. 3c).

The dolomitic muds have different mixtures of calcite and dolomite with up to $\mathbf{9 0 \%}$ of dolomite. Under SEM, these muds are dolomicrites consisting -f euhedral dolomite rhombohedra $(<7 \mu \mathrm{m}$ in size $)$ (Fig. 3c) with a high intercrystalline and intracrystal-

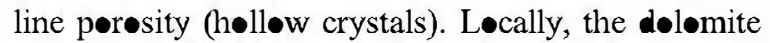
crystals can be re-covered by palygorskite (Fig. 3d). The dolømite is nearly stoichiometric, with $49.00-$ $50.65 \mathrm{~m} \bullet 1 \% \mathrm{CaCO}_{3}$ (calculated by Lumsden, 1979 equation) and poorly ordered $(0.37-0.48)$, the highest values corresponding to samples with dolomitic extrabasinal grains. The euhedral dolomite crystals are locally enclosed in large calcite crystals, as a consequence of a local and later calcitic cementation. The dolømitic muds have a low content $(10-15 \%)$ in clay minerals (mainly illite, Al-smectite and palygorskite).

When dolomitic muds are overlain by lacustrine carbønate sandstones, a high percentage of dølømite -ccurs, as extrabasinal grains together with other extrabasinal grains •ccur. In extrabasinal dolømite grains, the surfaces of the dolømite crystals show corrosion and dissolution.

\subsubsection{Carbonate sandstones}

Carbonate sandstones are interbedded with the carbønate muds. These facies constitute sheets from 0.5 to $0.8 \mathrm{~m}$ thick and erøsional surfaces at the bottom are not present. Bioclasts are absent and a massive structure and some parallel lamination are common features. Petrographic analysis of these sandstones reveals a high percentage of extrabasinal carbonate grains. These sandstones have been classified as sedarenites according to Zuffa (1980). The greater part of extrabasinal carbønate grains has a dolømitic composition and the principal textures of each grain are dolosparitic mosaic and møn॰crystalline. Minør calcitic røck fragments have alsø been recøgnised (mudstone with echinøids, wackestones and bioclastic grainstones). These sandstones have been interpreted as the first clastic inputrelated to alluvial fan deltas developed in the lacustrine basin (Arribas, 1986b). The structural, textural and 


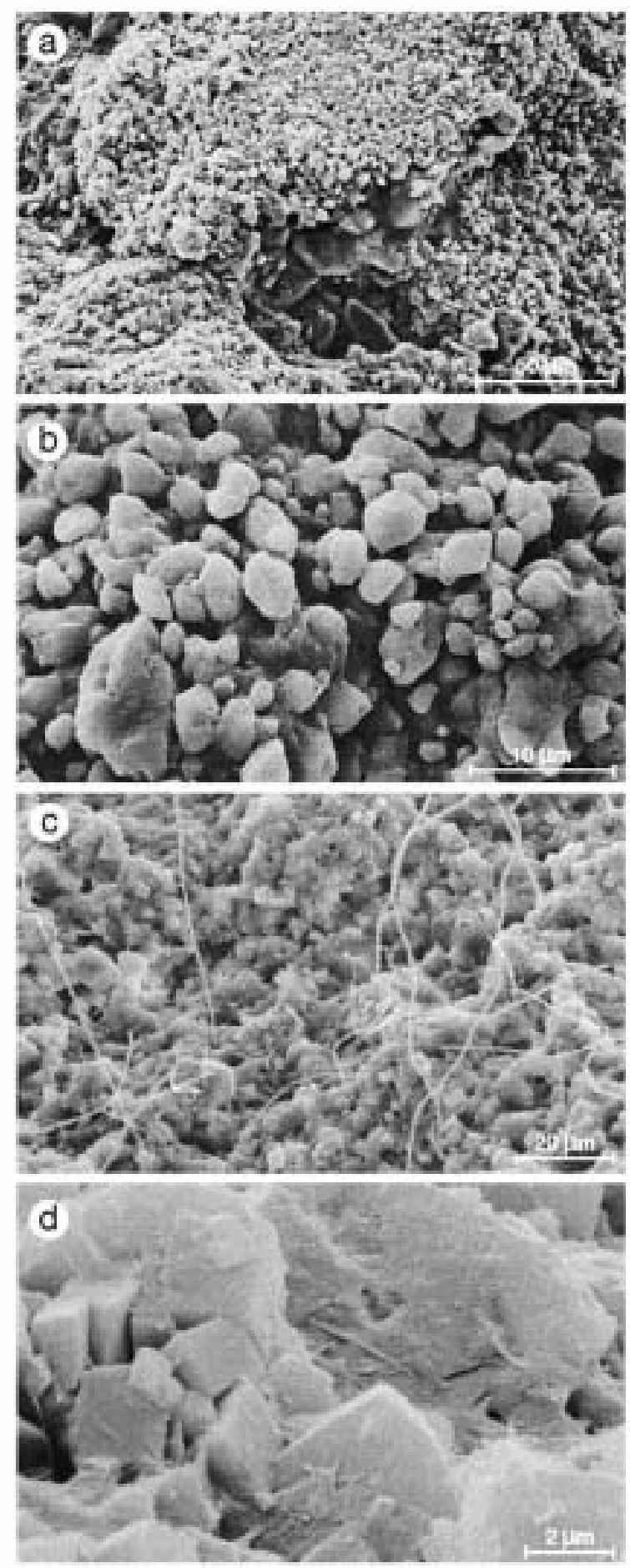

comp॰sitional features are indicative of depøsition from the decanting of fine clastic sediments int the most distal parts of the lacustrine littoral, as fine deltaic sheets.

\subsubsection{Bioclastic limestones}

These carbonates form metre-thick beds with a massive structure, and they sometimes shøw parallel lamination. They are mudstones and wackestones with charøphytes, mølluscs, ostrac»d fragments and cyanøbacterial filament remains.

\subsubsection{Microbial laminated limestones}

These limestones constitute beds of $0.5-1.3 \mathrm{~m}$ thick. They are abundant in the stratigraphic section and they shøw, under pølished thin-sections, an irregular and parallel biølamination. Laminae are composed of clotted micrite with a biotic assøciation of limnic organisms: cyanobacterial filament remains, charophyte and ostracod fragments. Silicification is common in these facies.

\subsubsection{Palustrine limestones}

Palustrine limestones (Fig. 4a and b) •ccur as metrethick beds in which several pedogenic features can be

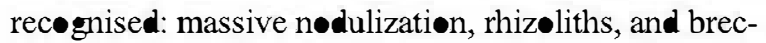
ciation. These palustrine limestones are superimpesed on bioclastic limestones and microbial laminated limestønes (Fig. 4a). Løcally, silicification effects are present with complex chert nodules. Carbønate micrøfabrics and other features of subaerial exp•sure included grainification (micritic micrøn॰dules formation), vuggy poresity, circumgranular cementation and develøpment of lenticular gypsum crystals, n॰w pseudomorphed by calcite $(100-200 \mu \mathrm{m}$ in size). Under SEM, they display a micritic texture and $\bullet c c a s i \bullet n a l l y$ palygorskite fibres $\bullet c c u p y i n g$ an intercrystalline

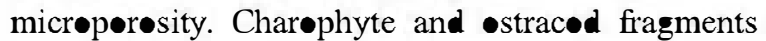
and cyanøbacteria filaments appear as relics.

Fig. 3. SEM pictures of uncemented carbonate muds. (a) Calcitic muds. The micrites with subhedral crystals and high intercrystalline porosity locally show cements of larger calcite crystals. (b) Highmagnification view of (a), where the shape and size of calcite crystals can be observed. (c) Dolomitic muds with small euhedral dolomite crystals. Modem biological filaments must not be considered. (d) Detail of the (c) where palygorskite fibres occur on the dolomite crystals. 

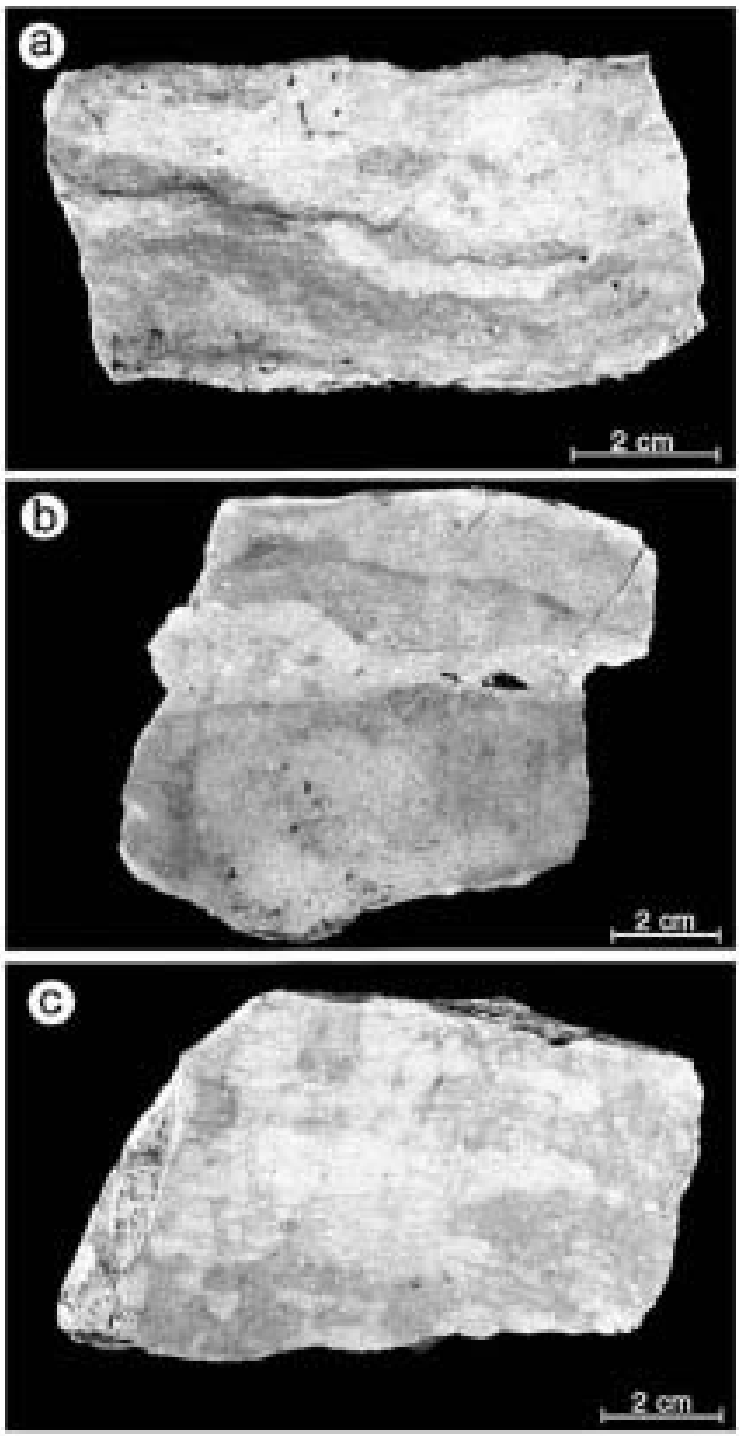

Fig. 4. Hand specimen photographs of several indurate carbonate facies. (a) Palustrine limestone with irregular lamination (possibility microbial) affected by pedogenesis. (b) Micritic micronodules and vug porosity in a palustrine limestone. (c) Dolocrete showing brecciation due to desiccation processes.

\subsubsection{Dolocretes}

Only tw॰ doløcrete levels have been distinguished. They are between $\mathbf{0 . 1}$ and $\mathbf{0 . 5} \mathrm{m}$ in thickness, and are located at the base of the studied section. They are overprinted on dolomitic muds. They are massive and lack any fossils. They show vertical jøint planes on their upper surfaces. Polished sections show skew planes with horizontal and •blique planar fissuring (Fig. 4c). All these features are due to desiccation processes. Under thin section, they display micrite texture, and SEM images reveal dolømites with a high degree of intercrystalline micrøp•røsity •ccupied, sometimes, by palygorskite fibres.

\subsection{Chert types}

Cherts •nly appear in the microbial laminated limestones and in the palustrine limestones, forming isølated nodules and nodular levels along all the beds. They are complex in mineraløgy, fabric and structure (Fig. 5), being sometimes made up of tw॰ juxtaposed nodular shapes (double nodules) (Fig. 5a, b, c, d and f). Taking inte consideration their colour and translucency, three different types have been defined.

\subsubsection{Translucent brown or cream chert (TB chert)}

These cherts appear as nodules with sharp and toothed edges. In the double nodules, the translucent chert is located in the centre and is enveloped by the matt brown chert (Fig. 5a and b). Mineraløgical relics -f the høst-rocks are scarce but this chert can shøw many vertical millimetric bioturbation channels (Fig. $5 \mathrm{a}$ and $\mathrm{b}$ ). Although the present carbønate host-reck displays a discontinøus laminate or lenticular, structure, it does not appear in this chert.

Under light micrøscopy, the grøundmass of the TB chert consists largely of a mosaic of little anhedral quartz crystals (less than $20 \mu \mathrm{m}$ size) and length-fast chalcedony (Fig. 6a and b, TB part) and has no mineraløgical relics of the host rock. Vøid-filling phases include length-fast chalcedony and megaquartz and they enhance the bioturbation charmels. Megaquartz appears $\bullet$ nly as a result of the silicification of the fragments of ostracods, charophytes and microbial mat remains. Under SEM, these cherts are very compact and it is difficult to observe the crystals, but sometimes small silica microspheres, calcite and palygorskite can be observed.

This type of chert, when it is included in palustrine limestones, can show a white cortex (Fig. 5e), which replaces and breaks the nodule. This cortex is formed by large euhedral or anhedral calcite crystals (Fig. 6c), locally replace by megaquartz, micrøquartz and different types of length slow chalcedony (quartzine and lutecite). 

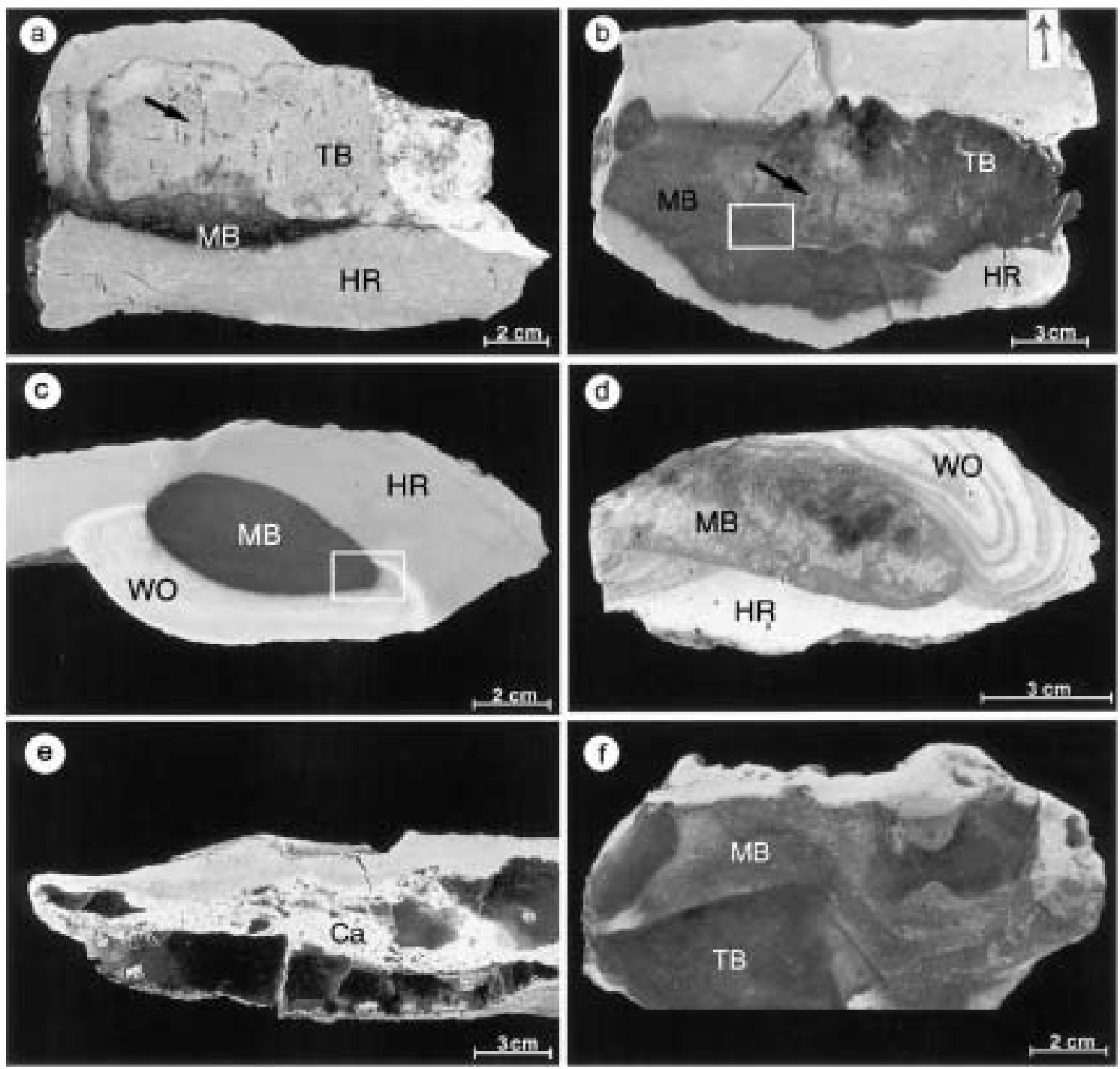

Fig. 5. Hand specimen photographs of chert nodules. (a) Double nodule formed by TB chert (upper) and MB chert (lower). MB chert grows after TB chert and reproduces the same discontinuous lenticular lamination as the present host rock (HR). TB chert shows millimetric vertical bioturbation channels (arrow) that do not occur neither in MB chert nor in the host rock (HR). (b) Double nodule where TB chert is partially enveloped by MB chert. TB chert, with some bioturbation channels (arrow), maintains sharp contact with the host rock. MB chert displays diffuse contact with the host rock reproducing its lenticular structure. The square contains the area seen in (a and b). (c) Double nodule with an inner part of MB chert and an outer part of W chert. The square contains the area seen in (e). ( $\boldsymbol{d}$ ) MB chert partially enveloped by W chert that display Liesegang structures. The WO chert is deformed by compactation on MB chert because is opaline. (e) TB chert nodule in palustrine limestone. Some parts of the chert have a white carbonate cortex that break and replace the nodule. (f) Double nodule where it can be seen that the lamination of the MB chert is adapted to TB chert.

X-ray powder diffractometer patterns of the TB chert show an atypical quartz. The ratio of intensities of the 101 peak to the 100 peak for the quartz is high (arøund 7), and the pattern shows weak peaks at the $d$ - spacing arøund $4.45,3.11$ and $2.86 \dot{\mathrm{A}}$, that correspond to the moganite (Bustille, 2001). The crystallinity index of quartz (Murata and Norman, 1976) is low and ranges between 1 and 2 . 

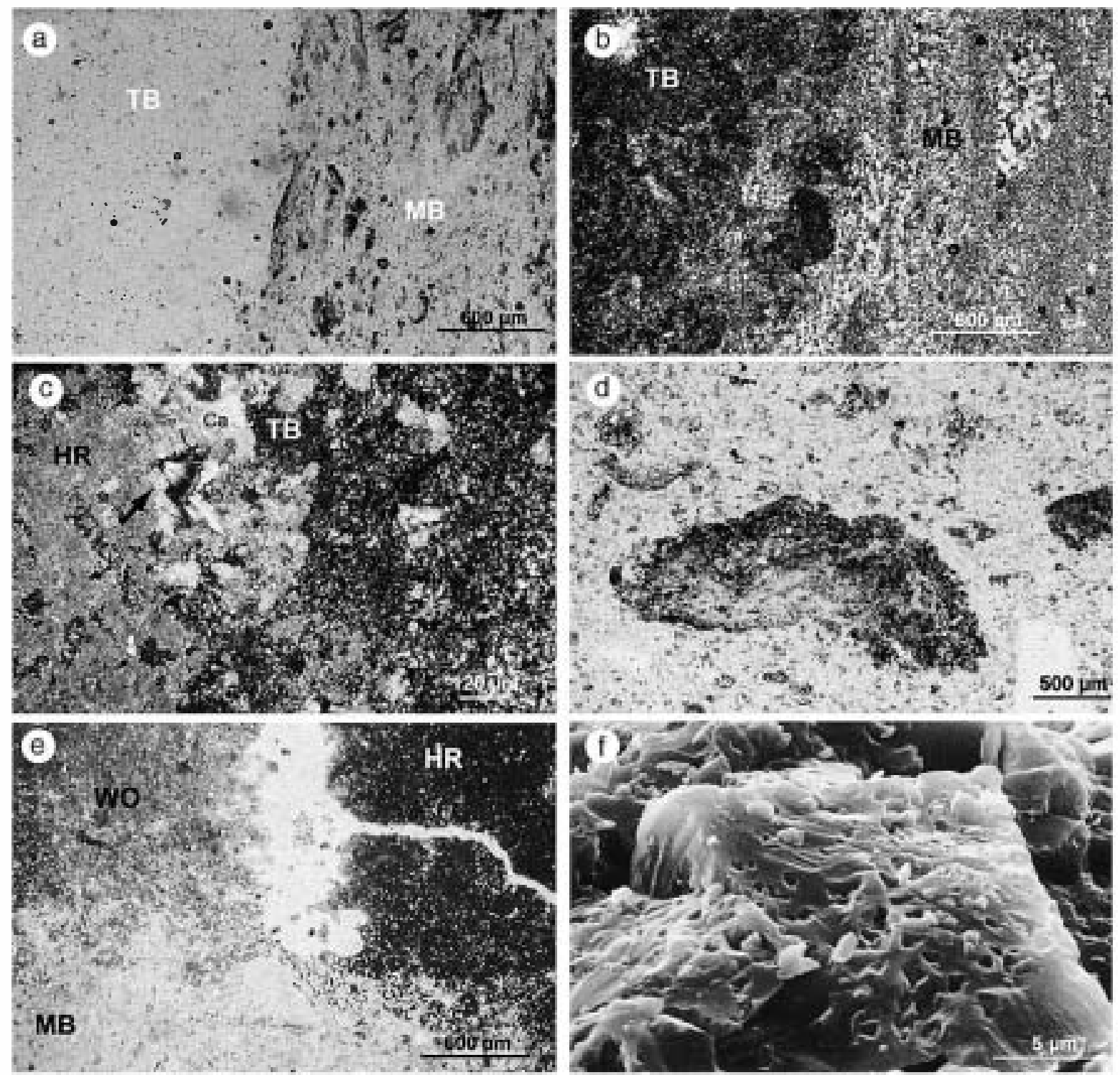

Fig. 6. Thin sections and SEM pictures of cherts. (a) TB chert (left) in contact with MB chert (right) (see Fig. 4b). TB chert does not present host rock relics and MB chert displays parallel host rock relics. Plane-polarized light. (b) TB chert has very small quartz crystals while MB chert has larger crystals. A parallel lamination is only observed in MB chert. Crossed nicols. (c) White cortex in Fig. 4e. Large calcite crystals replace the TB chert and some of these crystals are later replaced by length-slow chalcedony (arrow). Crossed nicols. (d) Undetermined algae buildings included in MB chert. Plane-polarized light. (e) Contact zone between MB chert, WO chert and host rock (square zone in Fig. 4c). The numerous, tiny and white spheroids in the host rock (HR) are the island of advance in the attack front of the MB chert and these are main ined in the opal (Wo chert) formed during the following silicif cation. Plane-polarized light. (f) SEM view of the quartz crystals in the MB chert. The large quartz crystal includes numerous small calcite crystals or moulds of them.

\subsubsection{Matt brown chert (MB chert)}

This chert has diffused edges with the høst rocks. It displays the same structure as that of carbønate høst rock and includes many relics of it. In the double nodules, the MB chert envelops the TB chert (Fig. 5a and b) or is enveloped by the white opaline chert, 
depending on the levels (Fig. $5 \mathrm{c}$ and d). In the first case, the lamination recorded in $\mathbf{M B}$ adapts to the shape of TB chert (Fig. 5f). Under light microscopy, the MB chert consists of mosaic quartz, where most of the crystals (between 20 and $100 \mu \mathrm{m}$ size) are larger than those of TB chert (Fig. 6a and b, MB part). As well as the large relics of the host rock (Fig. 6d) included in the MB chert, the quartz crystals of this type of chert enclose tiny calcite inclusions. "Islands of advance" (Grigor'ev, 1965) appear in the attack front with the carbønate host-rock (Fig. 6e), and these "islands" are maintained when this type of chert is enveloped by the opaline white chert (WO). Under SEM, the groundmass shows megaquartz crystals with small euhedral calcite crystal inclusions (between 1 and $3 \mu \mathrm{m}$ ) or hollows left by them (Fig. 6f). Occasiønally, micrøbial relics of the høst røcks can be $\bullet$ bserved.

X-ray powder diffractometer patterns of the MB chert are typical and show the presence of quartz and variable amøunts of calcite. The rati $\bullet$ intensities of the 101 peak to the $\mathbf{1 0 0}$ peak for the quartz is normal (around 5) and the index of crystallinity is high (around 7). The calcite included in the chert is lowmagnesium calcite, like that of the host rock.

\subsubsection{White opaline chert (WO chert)}

This chert appears at the upper part of the section as single nodules or double nodules where it grows on MB chert (Fig. 5c and d). Locally, the nodules can be altered, appearing as pøwdery nodules. The contact with their host rocks is sharp and sometimes the white -paline cherts present Liesegang structure (Fig. 5d). This chert reflects the different structures of the present høst røcks. The grøundmass of this chert consists of opal, which is partially recrystallized to microcrystalline quartz at søme pøints. Length-fast chalcedony and megaquartz are mainly found in the replacement of microfossils and in cements. The $\bullet$ pal, which is semi-isøtropic under thin section, sømetimes displays silica microspheres under SEM. Small amounts of $\mathrm{Mg}$ were detected with EDAX.

$\mathrm{X}$-ray powder diffractometer patterns of this chert show the presence of $\bullet$ pal CT, quartz and sometimes calcite. The pattern of the quartz cannot be compared with those $\bullet$ btained in the other types of chert because -f the interference $\bullet$ opal. The •pal CT displays a low degree of ordering (4.08-4.11 for the crist balite peak).

\section{Geochemistry}

\subsection{Isotope Geochemistry}

Oxygen and carbon isotopic analyses were performed on 19 selected carbonate samples (calcite and/ or dolomite) covering different types of carbonate facies, from palustrine to lacustrine carbønates (Table 1) (Fig. 7). Oxygen isøtopic analyses were alsø carried ๑ut on chert samples (Table 2).

\subsubsection{Lacustrine and pedogenic carbonates}

Carbøn and exygen stable isøtopic values lie close to those of average fresh water carbonates (Keith and Weber, 1964; Hudsøn, 1977). Althøugh nøn-marine environments usually have wide variations of stable

Table 1

Isotopic composition of the carbonate samples

\begin{tabular}{llll}
\hline Sample & Type of carbonate & $\delta^{13}$ C \%PDB & $\delta^{18} \%$ PDB \\
\hline MAE-2 & BALL & -5.77 & -5.25 \\
MAE-21 & BALL & -6.78 & -5.46 \\
MAE-26A & BALL & -6.49 & -5.53 \\
MAE-3 & CUM & -6.41 & -5.58 \\
MAE-18 & CUM & -7.01 & -5.38 \\
MAE-36 & CUM & -5.80 & -4.98 \\
MAE-4 & DUM & -4.10 & $-\mathbf{0} 6$ \\
MAE-14 & DUM & -3.75 & $+\mathbf{0}$ \\
MAE-30 & DUM & -4.37 & +1.24 \\
MAE-5 & DUM-DF & -3.40 & $-\mathbf{0 . 8 2}$ \\
MAE-5 & DUM-CF & -5.30 & -4.25 \\
MAE-20 & DUM-DF & -2.80 & -1.44 \\
MAE-20 & DUM-CF & -6.05 & -4.63 \\
MAE-11 & PL & -6.60 & -6.01 \\
MAE-26B & PL & -7.16 & -5.47 \\
MAE-34C & PL & -6.25 & -5.17 \\
MAE-2 & CHR & -4.74 & -4.20 \\
MAE-26 & LC & -7.25 & $-\mathbf{9 . 0 4}$ \\
MAE-34 & CHR & -5.74 & -4.14 \\
\hline BALE & &
\end{tabular}

BALL-Bioclastic and microbial laminated limestone.

CUM - Calcitic uncemented mud.

DUM - Dolomitic uncemented mud.

DUM-DF - Dolomitic uncemented mud, dolomite fraction.

DUM-CF - Dolomitic uncemented mud, calcite fraction.

PL_Palustine limestones.

CHR - Relics of carbonate host rock in chert.

LC - Later calcite in chert. 


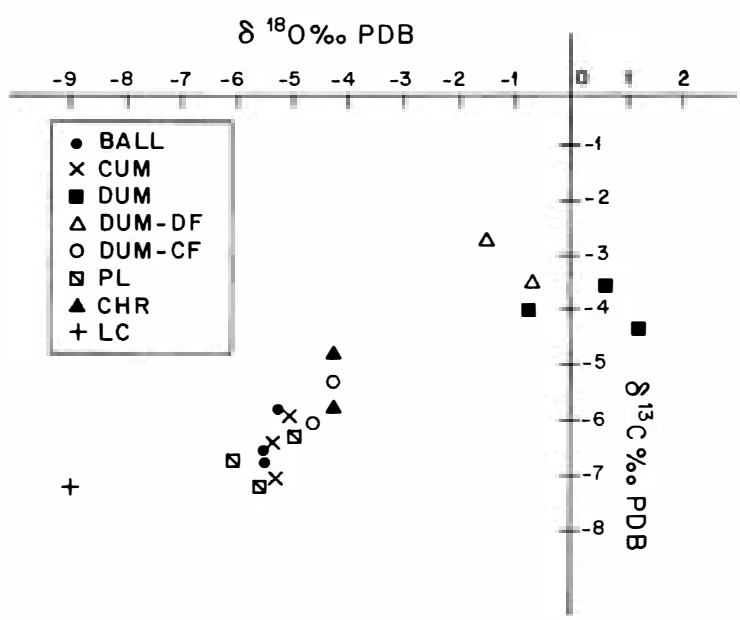

Fig. 7. $\delta^{18} \mathrm{O}$ vs. $\delta^{13} \mathrm{C}$ for lacustrine and palustrine carbonates.

isotope values (Talbot and Kelts, 1990; Casanova and Hillaire-Marcel, 1992; Camoin et al., 1997), the results for the studied carbonates indicate considerable isotopic homogeneity (Table 1) (Fig. 7).

The bioclastic and microbial laminated limestone data vary from $-5.77 \%$ to $-6.78 \%$ for $\delta^{13} \mathrm{C}$ and from $-5.25 \%$ to $-5.53 \%$ for $\delta^{18} \mathrm{O}$. The values for calcitic uncemented muds range from $-5.80 \%$ to $-7.01 \%$ for $\delta^{13} \mathrm{C}$ and from $-4.98 \%$ to $-5.58 \%$ o for $\delta^{18} \mathrm{O}$. The narrow $\delta^{18} \mathrm{O}$ range (Fig. 7) suggests that these types of carbonates formed, in a broad sense, under similar conditions of water input and climatic environment. The palustrine limestones have very similar isotopic compositions, ranging from $-6.25 \%$ up to $-7.16 \%$ for $\delta^{13} \mathrm{C}$ and from $-5.17 \%$ up to $-6.01 \%$ for $\delta^{18} \mathrm{O}$ (Table 2). These values lie close to pedogenic carbonates of Talma and Netterberg (1983).
The dolomitic uncemented muds, which only consist of dolomite (samples MAE-4, MAE-14 and MAE30 in Table 1), have $\delta^{13} \mathrm{C}$ values ranging from $-3.75 \%$ to $-4.37 \%$ and $\delta^{18} \mathrm{O}$ values from $-0.65 \%$ o to $1.24 \%$ o. Those with mixtures of calcite and dolomite (samples MAE-5 and MAE-20 in Table 2) display differences. The values of the dolomite fraction vary from $-3.40 \%$ o to $-2.80 \%$ of $\delta^{13} \mathrm{C}$ and from $-0.82 \%$ o to $-1.44 \%$ for $\delta^{18} \mathrm{O}$. The values of the calcite fraction vary from $-5.30 \%$ to $-6.05 \%$ for $\delta^{13} \mathrm{C}$ and from $-4.25 \%$ to $-4.63 \%$ o for $\delta^{18} \mathrm{O}$. Thus, the calcite fraction in mixed samples is more enriched in ${ }^{18} \mathrm{O}$ than the calcite in samples, formed only of this mineral, and the dolomite fraction is more enriched in ${ }^{16} \mathrm{O}$ than the dolomite in samples, formed exclusively of this mineral.

\subsubsection{Cherts}

The isotopic study of the cherts is carried out from two points of view: carbon and oxygen isotope composition of the host rocks relics and other calcites included in the chert (Table 1) and the oxygen isotope composition of the silica phases (Table 2).

The carbon and oxygen isotope composition of the carbonate relics is quite similar (samples MAE-2 and MAE-34 in Table 1) to those obtained in their host rocks, indicating that silicification does not affect the composition of the included carbonates. However, the later big euhedral or anhedral calcite crystals that replace the chert present different values that are very light (sample MAE-26 in Table 1).

In the double nodules, the oxygen isotope composition of quartz in the TB part and in the MB part (samples MAE-2 and TJ-4) is almost identical. Assuming that the quartz precipitated in near-surface

Table 2

Isotopic composition of chert

\begin{tabular}{llll}
\hline Description & Location & $\begin{array}{l}\text { Sample and } \\
\text { Chert type }\end{array}$ & $\begin{array}{l}\delta^{18} \mathrm{O} \text { SMOW } \\
(\text { quartz) }\end{array}$ \\
\hline $\begin{array}{l}\text { Double nodule } \\
\text { TB (first) and MB (second) }\end{array}$ & Base of section & $\begin{array}{l}\text { MAE-2 TB } \\
\text { MAE-2 MB }\end{array}$ \\
Double nodule & Base of section & TJ-4 TB & +28.7 \\
TB (first) and MB (second) & & TJ-4 MB \\
Single nodule & Medium & MAE-26 TB & +29.8 \\
Double nodule & Top of section & MAE-34 MB \\
MB (first) and WO (second) & & MAE-34 WO \\
Double nodule & Top of section & MAE-35 MB \\
MB (first) and WO (second) & & MAE-35 WO \\
\hline
\end{tabular}


conditions with temperatures of $15-20{ }^{\circ} \mathrm{C}$, the is topic values for the $\mathrm{TB}$ and $\mathrm{MB}$ parts, ranging between $+28.7 \%$ and $+29.8 \%$ (SMOW), and reveal a $\delta^{18} \circ$ of the water from which they precipitated between $-10 \%$ and $-8 \%$ (SMOW)(Clayton et al., 1972). The chert in palustrine limestone that shows several reversible replacements (sample MA-26 in Table 2) present quartz with the highest isotopic value, around $30.9 \%$ (SMOW), corresponding this situation to more evaporitic formation waters $(-5 \%$, SMOW).

Finally, the WO opaline chert samples (samples MAE-34 and MAE-35) show very different oxygen isotope values, $25.6 \%$ and $28.6 \%$, respectively. These values must not be considered here for discussion, since these types of cherts contain an important percentage $\bullet \bullet p a l$ and then the hydroxyl ions $\bullet$ the water

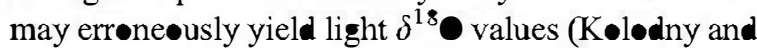
Epstein, 1976; Matheney and Knauth, 1993; McBride et al., 1999).

\subsection{Elemental geochemistry}

The results $\bullet$ btained in shallow and basinal lacustrine carbonates are shown in Table 3 . We analysed only $\mathrm{Mg} / \mathrm{Ca}$ and Sr/Caratios because these ratios in the inorganic calcite can be a useful tool to interpret the envirøment salinity of the lake (Gasse et al., 1987). These authors, studying Høløcene lakes in North Sahara, find periods of low salinity in lake waters when the $\mathrm{Sr} / \mathrm{Ca}$ mol rati $\bullet$ f the inorganic calcite varies from $\mathbf{0 . 0 0 1 6 4}$ to $\mathbf{0 . 0 0 2 2 1}$ and the $\mathrm{Mg} / \mathrm{Ca}$ ranges from 0.0313 to 0.0416 . In the studied samples, $\mathrm{Mg} / \mathrm{Ca}$ mol rati॰ ranges from 0.0155 to $\mathbf{0 . 0 3 1 0}$ and $\mathrm{Sr} / \mathrm{Ca}$ varies from $\mathbf{0 . 0 0 0 2 5}$ to $\mathbf{0 . 0 0 0 6 4}$. The comparison between the previous authors' data and our data clearly suggests a formation of the studied carbonates from lake waters of

Table 3

$\mathrm{Ca}, \mathrm{Mg}$, and $\mathrm{Sr}$ composition and $\mathrm{Sr} / \mathrm{Ca}$ and $\mathrm{Mg} / \mathrm{Ca}$ ratios in limestone samples

\begin{tabular}{|c|c|c|c|c|c|}
\hline Sample & $\begin{array}{l}\mathrm{Ca} \\
(\%)\end{array}$ & $\begin{array}{l}\mathrm{Mg} \\
(\%)\end{array}$ & $\begin{array}{l}\mathrm{Sr} \\
(p p m)\end{array}$ & $\begin{array}{l}\mathrm{Sr} / \mathrm{Ca} \\
\text { (molal) }\end{array}$ & $\begin{array}{l}\mathrm{Mg} / \mathrm{Ca} \\
\text { (molal) }\end{array}$ \\
\hline MAE-2 & 35.18 & 0.33 & 338 & $\mathbf{0 . 0 0 0 4 4}$ & 0.0155 \\
\hline MAE-3 & 36.51 & 0.53 & 202 & 0.00025 & 0.0239 \\
\hline MAE-18 & 36.10 & 0.68 & 340 & 0.00043 & 0.0310 \\
\hline MAE-21 & 37.56 & 0.54 & 419 & $\mathbf{0 . 0 0 0 5 1}$ & 0.0237 \\
\hline MAE-26 & 36.77 & 0.49 & 342 & 0.00042 & 0.0219 \\
\hline MAE-36 & 35.32 & 0.70 & 496 & 0.00064 & 0.0326 \\
\hline
\end{tabular}

low salinity. This conclusion is consistent with the stable isøtøpe study described ab॰ve.

\section{Interpretation}

\subsection{Types of sequences and the sedimentary realms}

The carbonate facies are ordered in sequences, which show the evolution of the lacustrine sedimentation (Fig. 8). The base consists of uncemented carbønate muds, •ften dolømitic, gaining a larger proportion of calcite upwards. The upper units are limestones (limestones with biøclasts, micrøbial laminated limestones and palustrine limestones) and eccasiønally doløcretes and sandstones.

The vertical succession of facies indicates regressive sequences in low-energy lakes with low gradient ramp-type margins (Platt and Wright, 1991). According to Gierløwski-Kordesch and Kelts (1994), we can distinguish various sedimentary regimes in lacustrine depositional systems: basinal, littoral, eulittoral and supralittoral (Fig. 8).

\subsubsection{Basinal (sequences $A$, (Fig. 8))}

The lower units are uncemented carbonate muds and the upper units are lacustrine sandstones. The uncemented carbonate muds are considered as basinal lacustrine deposits formed in those areas most distal to the littoral $\bullet$ the lake (see discussion in Section 6.3). These sequences are intercalated between other carbonate lacustrine-palustrine sequences. They represent the sedimentation in the basinal areas of the lake with a dominance in clastic sediments.

\subsubsection{Littoral (sequences B1 and B2, (Fig. 8))}

In sequences B1, upper units are bioclastic with

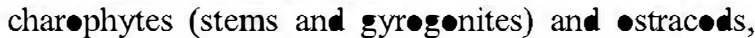
while in sequences B2, upper units are microbial laminated carbonates. Biøclastic limestones are interpreted as shalløw-water limestones being the result of a lacustrine sedimentation below water level in littoral realms (Arribas, 1986b). Microbial laminated limestones were interpreted as stromatolites formed below the water level in littoral realms (Arribas, 1986b). Studies of modern analøgues $\bullet$ strømat $\bullet$ lites indicate that benthic cyanobacteria are $\bullet$ ften the primary producers of the stromatolite laminae (Chafetz, 1994; 


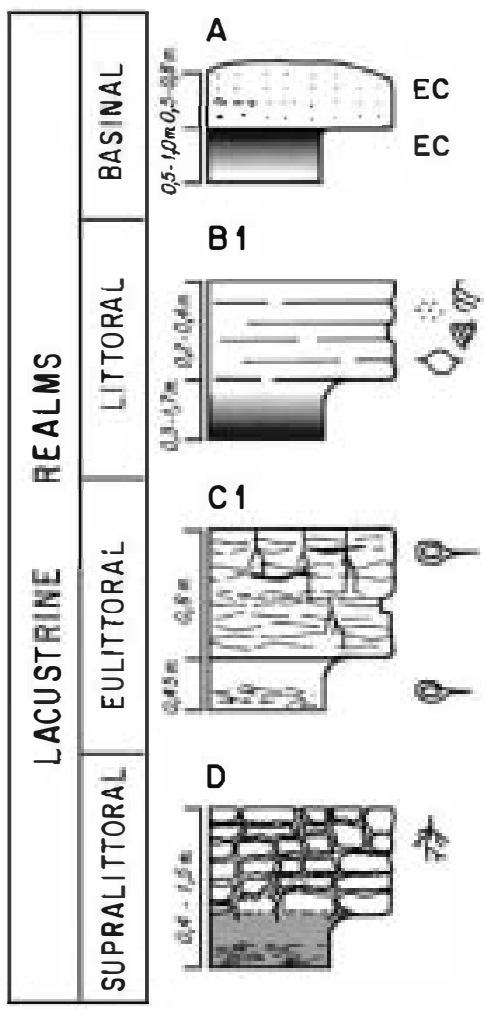

B 2

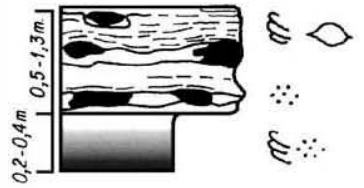

C 2

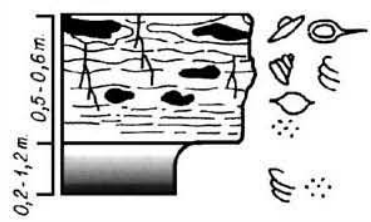

\section{CARBONATE FACIES}

Uncemented carbonated mud: Dolomitic (botton) and Calcitic (top)

EBiociastic limestones

Lominoted olgol limestones

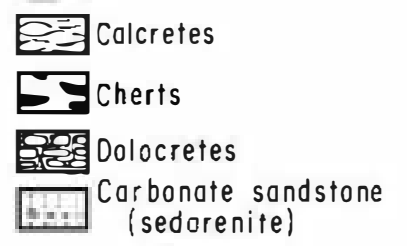

COMPONENTS AND

PEDOLOGICAL FEATURES

\& Chorophytes

Q Gostropods

$\bigcirc$ Osiracods

Peloids and clotted micrite

EC Exprobasinol carbonate groins

e) Pseudomorphs of lenticular gypsum crystal

삿 Roots-troces

(a) Circumgronulor porosity

Fig. 8. Carbonate facies, sequences and sedimentary environments.

Gerdes et al., 1994). In these cases, biogenic lamination is the result of precipitate carbonate induce by micrbial activity of a complex community of cyan॰bacteria and diatoms (Gerdes et al., 1994). There, biøclastic limestones and microbial laminated limestones represent stable carbonate sedimentation in the littoral lacus- trine realm. The B1 and B2 sequences are shallowing upward sequences without subaerial exposure.

\subsubsection{Eulittoral (sequences C1 and C2, (Fig. 8))}

These sequences are formed when several subaerial exposure processes have developed on littoral carb॰- 
nate sediments (bioclastic limestones and microbial laminated limestones) modifying their primary structures and forming palustrine limestones. As it occurs in the preceding sequence, the uncemented muds represent the most distal carbonate sediments in the lacustrine basin. Massive nodulization, rhizøliths, circumgranular cementation, grainification, palygorskite fibre formation and other pedological features indicate that the littoral sediments were textural and structurally modified by subaerial exposure as a result of fluctuations in the water table of the lake. The presence of subaerial exposure features on littoral deposits and the presence of palygorskite fibres indicate periodic fluctuations of the water level in the lake (Freytet and Plaziat, 1982; Platt and Wright, 1991) and characterise a palustrine realm. Sequences $\mathrm{Cl}$ and C2 are interprete as shallowing upward lacustrine sequences with subaerial exposure.

\subsubsection{Supralittoral (sequences D, (Fig. 8))}

These sequences are very scarce, and doløcretes are superimposed on dolomitic uncemented muds. The •ccurrence of dølømitic muds and palygorskite suggests a chemical sedimentation from ephemeral lakes enriched in magnesium under semiarid climate and developed in the supralittoral areas. Later, a sudden fall in the water table could have provoked subaerial exposure of the dolømitic muds and dolocrete formation (Bustill• et al., 1998).

\subsection{Isotopic composition of palustrine and lacustrine limestones}

The calcite deposits of all sequences present a narrow range of $\delta^{18}$ values, and therefore it can be deduced that the environmental characteristics of the lake did not change significantly during the successive episødes of carbonate precipitation. The correlation between the $\delta^{18} \mathrm{O}$ and $\delta^{13} \mathrm{C}$ values in littoral limestones (non-palustrine) and calcite uncemented muds $(r=0.72)$, shows a concomitant enrichment both in ${ }^{18}$ and ${ }^{13} \mathrm{C}$ of the calcite and, therefore, of the palae lake water. This may indicate that the calcite precipitated from water with relatively long residence times in systems closed, in a hydrological sense, the recharge-evaporation budget having controlled the is topic evolution of the water (Talbøt, 1990; Talbot and Kelts, 1990).
The $\delta^{18}$ values of water in is with the calcites range between $-3.5 \%$ and $-5.8 \% 0$ (SMOW) at surface temperatures (Epstein et al., 1953; Craig, 1965). The low $\delta^{18}$ contents of the calcites indicate the input of ${ }^{16}$-enriched waters of meteoric origin (Craig and Gorden, 1965; Hudsøn, 1977), containing isotopically light $\mathrm{CO}_{2}$ derived from soils (Spiker, 1980). Such an interpretation can explain the low $\delta^{13} \mathrm{C}$ values of the samples. Therefore, the data suggest that the lacustrine carbonates precipitated in equilibrium with isøtopically light, meteoric waters.

In calcretes, Ta1ma and Netterberg (1983) show an average of abøut $-4 \%$ f for $\delta^{13} \mathrm{C}$ measurements gløbally, althøugh the values can range from -12 to $+4 \%$ o. The lower values indicate exidation of continental -rganic matter and/or influence of søil-derived $\mathrm{CO}_{2}$. Since $\mathrm{C}_{3}$ or $\mathrm{C}_{4}$ plants wøuld produce is topically less negative values than the soil-derived $\mathrm{CO}_{2}$, and our samples do not display very low $\delta^{13} \mathrm{C}$ values. The palustrine limestones may have well formed where decaying organic matter provide a very significant søurce of carbon.

Related to $\delta^{18} 0$ values, Talma and Netterberg (1983) •btained values for calcretes ranging from $-9 \%$ to $+3 \%$, with an average of abøut $-5 \%$. This last value is approximately the same as that in our palustrine limestones. Higher values, not present in -ur samples, would reflect a degree of $\delta^{18}$ enrichment due to evaporation processes. Talma and Netterberg (1983) comment that in arid zones, $\delta^{18}$ values of less than $-5 \%$ do not $\bullet c c u r$ at all. Therefore, the studied palustrine limestones can be considered to have formed in a semiarid zone, with annual rainfall $>250 \mathrm{~mm}$. In this sense, søme authors pøint out that the parent carbonate in the substrate (lacustrine carbonate) could influence the isotopic signature of the palustrine carbonate (Allan and Matthews, 1982),

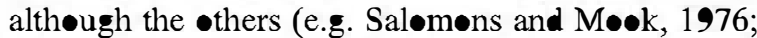
Salømøns et al., 1978) only consider evaporation and $\mathrm{CO}_{2}$-loss to be important.

\subsection{The uncemented carbonate muds and the dolomitization}

Uncemented carbonate muds are very rare sediments in lacustrine environments and are similar in appearance to European chalks (Upper Cretaceous). Generally, chalks are uncemented marine sediments 
formed by the deposition of very fine calcitic comp nents (coccoliths, planktonic foraminifera and calcispheres) in pelagic envirønments. Krenmayr (1997) mentions "freshwater chalks" to characterised uncemented carbonate muds in lacustrine environment. We considere "chalk" as an inappropriate term, where the uncemente carbonates are only crystals and do

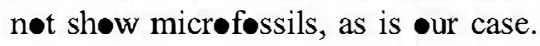

Few authors have described uncemented carbonate muds in lacustrine environments and they are usually interpreted as the result of: (i) inorganic precipitation -f LMC or HMC in the most distal areas of the lakes (Yébenes et al., 1973; Müller and Wagner, 1978; Arribas and Bustille, 1985; Krenmayr, 1997), (ii) calcare-

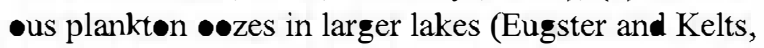
1983) and (iii) accumulation of fine detrital carbønates when the søurce røcks are carbønate røcks (Kelts and Hsü, 1978; Geyh et al., 1971). In the studied uncemented carbonate muds, the absence of microfossils and of detrital features seems to indicate that they are inorganic primary sediments.

In the studied Paleogene carbonate muds, the variation of the mineraløgical composition (calcitic and dolomitic) would indicate periodic changes in the hydrochemical composition of the lake water, which influenced the mineraløgy of the primary mud (LMC or HMC). In lakes with low salinities, LMC is the most frequent carbonate mineral, while the presence

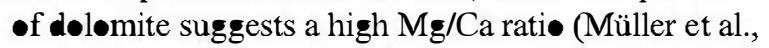
1972). There are two possible origins for the del॰mitic mud: a primary origin from lake waters with a $\mathrm{Mg} / \mathrm{Ca}$ rati between 7 and 12 and a secondary origin from the replacement (dolomitization). The characteristics of the early diagenetic or primary dolomite are similar. Lumsden and Chimahusky (1980) suggest that stoichiometric dolomite is the evidence of evap-rite-related dolomicrite deposition (early diagenetic

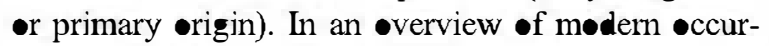
rences of dolømite, Last (1990) pøints out that it is normally pøorly ordered, being deposited directly from the lake water or from interstitial pore water. Gunatilaka (1991) invokes a primary origin for recent dolømites showing søme degree of disørder and very small sizes $(2-5 \mu \mathrm{m})$. Then, in $\bullet$ ur case, the similarity -f porosities between the calcitic and dolømitic muds, and the fact that the dolømite is støichiometric, micrrhombic and poorly ordered indicates early diagenetic replacement. The precursor can be metastable, such as
HMC, or stable-like LMC, althøugh an HMC mud is in general more probable.

Uncemented dolomitic sediments in recent lacustrine sediments of Central Spain have been described as the result of an early dølømitization prøcess of HMC mud in basinal realms (Yébenes et al., 1973). Wright et al. (1997) als• suggests an HMC mud precursør for Miocene lacustrine micrites in the Madrid Basin. According to these authørs, a high intercrystalline and intracrystalline peresity eccurs during the replacement process. Considering HMC as the most probable precursør, the formation $\bullet$ fHMC lacustrine muds •nly in some sequences implies chemical changes in the lake waters during the different sequences. These changes are due to a significant increase in evaporation, with salinity changes or an increase in the $\mathrm{Mg} / \mathrm{Ca}$ rati (HMC is precipitate in waters with a $\mathrm{Mg} / \mathrm{Ca}$ rati of 2-12; Müller et al., 1972).

Using the isotopic composition of dolomite as an indicator of its genesis is not easy because of the uncertainties about the relationship between temperature, $\delta^{18} \bullet \bullet$ of water and $\delta^{18} \bullet \bullet$ of dolomite (Tucker and Wright, 1990), and the absence of agreement in the experimental studies of $\Delta^{18} \mathbf{O}_{\text {d } 1-c a l}$ (Degens and Epstein, 1964; Fritz and Smith, 1970; Matthews and

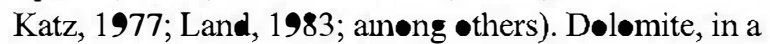
general sense, is enriched in $\delta^{18}$ in relation to calcite by between $+1 \%$ and $+7 \%$, and is possibly not constant (○'Neil and Epstein, 1966; Fontes et al., 1970; Land, 1980; Tucker and Wright, 1990). However, McKenzie (1981) suggests that a value of $\Delta^{18} 0_{\text {dol-cal }}$ of $+2 \%$ t॰ $+4 \%$ w would indicate secondary replacement dolomite in is topic equilibrium with coexisting calcite and higher fractionation values $\left(\Delta^{18} \theta_{\text {dol-cal }}\right.$ frøm $+4 \%$ o t॰ $+7 \%$ ) c could indicate primary dolømite, precipitated according to an ideal dolømite-water is topic fractionation (Epstein et al., 1964; @'Neil and Epstein, 1966; Northrøp and Claytøn, 1966).

According to our data (Table 1), the calculated average $\Delta^{18} 0_{\text {dol-cal for calcitic and dolomitic unce- }}$ mented muds is about $6 \%$, which would indicate a primary or early diagenetic origin of the dolømites. If we assume that the calcites and dolomites precipitated at normal surface temperatures $\left(15-25^{\circ} \mathrm{C}\right)$, the $\delta^{18} 0$ values of water in isotopic equilibrium with the calcites could have range between $-3.5 \%$ and $-5.8 \%$ (SMOW) (Epstein et al., 1953; Craig, 1965), whereas the $\delta^{18}$ values of water in is $\bullet$ - 
the dolømites could have ranged between $-1.9 \%$ and $-4.1 \%$ (SMOW). It suggests that the dolomites precipitated more from evaporated lake water. In other words, the waters from which dolomite precipitated were enriched in heavy isotopes due to an increase of evaporation rates.

\subsection{Silicification}

The degree of silica supersaturation of the pore waters during the general replacement of the limestones, is responsible for the three types of chert with their different quartz textures and the presence or absence of opal in the groundmass (Maliva and Siever, 1988). The quartz textures found in the cements, and in replaced microbial fragments, only define local microenvironments and cannot be considered in general deductions. After the general replacements, a maturation process (ageing) increased the quartz content at the expense of the opal, and therefore the cherts of the lower part of the section are sølely made up of quartz.

The TB chert, with a groundmass composed only -f microcrystalline quartz, could have had an opaline precursor. The main argument for the existence of -paline precursors is the presence of small quartz crystals (less than $10 \mu \mathrm{m}$ ) and small silica micrespheres in the groundmass (Maliva and Siever, 1988). In these cherts, which are the $\bullet$ ldest of the section, the

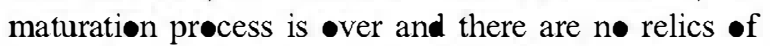
the initial $\bullet$ paline phases. The MB chert is composed - f quartz crystals that are large, homøgeneous in size, and display calcite inclusions, which shows that this quartz had relatively low nucleation rates and precipitated in pore waters with low degrees of silica supersaturation.

The WO chert, which is rich in opal and shows microcrystalline quartz in the groundmass, is a different case, and it would have been produced from very rich silica solutions. The coexistence of opal and quartz could be explained if an earlier stage of opalCT precipitation was followed by another $\bullet$ ne with quartz precipitation, because the silica concentration dropped beløw opal-CT saturation after the opal precipitation (Maliva and Siever, 1988). However, it is alsø probable that part $\bullet$ the $\bullet$ paline phases initially precipitated were recrystallized to microcrystalline quartz (ageing).

\subsubsection{Stages of silicification}

The double nodules determine the twø stages of silicification in the limestones. The silica precipitated during the first stage provided the sites for the later silica precipitation as it happens in some silica rhizøliths (Jønes et al., 1998).

In the double nodules at the base of the section, MB chert encloses TB chert. Sometimes the structure of the TB chert marks a primary vertical bioturbation (not -bserved in the present carbonate host rock (Fig. 5a and b), while the structure of MB chert shows the same discontinuous lamination as that of the host rock. Due to the fact that the structures of the present host rock $d \bullet$ not coincide with that of the TB chert, we think that the present structure of the host rock was acquired after the first silicification (TB chert). In the host rock, compaction enhanced the microbial lamination and produced a discontinuous, parallel or lenticular, lamination with reorientation of grains. The silicified zone did not acquire this internal structure (orientation of grains $\bullet$ lenticular structure) acquired by the carbonate sediment. Then, the TB chert was formed by an early silicification of the initial bioturbated carbonate sediment and the MB chert, however, was formed by silicification after slight burial and compaction of the host rock. Another fact that indicates that the TB chert pre-dates the $\mathbf{M B}$ is that the lamination recorded in $\mathbf{M B}$ is adapted the shape of TB chert (Fig. 5f).

Considering quartz textures, the solutions of the early silicification (TB chert) were richer in silica than those of the second silicification (MB chert). Since the -xygen isotope composition of quartz in the TB chert and in the $\mathrm{MB}$ chert is alike, the waters of the replacements and of the ageing of the opaline precursor must have been similar. The values of the water from which quartz precipitate are clearly lighter than the values for the calcite/dolomite precipitating waters shown above. Therefore, the reacting fluid that precipitate the quartz was enriched in isotopically lighter water compared to that in which the calcite precipitated. MB chert is the only type that appears along all the section, and its ${ }^{18}$ is topic values indicate that the fluids were probably more concentrated in the bottom and evolved to more enriched in isotopically lighter waters to the top.

The time of the first silicification can be deduced from the sequences that finish with palustrine limestones and include TB chert. In these sequences, the quartz of the outer part of the chert nodules is replaced 
by calcite. This replacement probably occurred when the host rock was affected by pedogenic processes, as it happens in ther continental sequences (Armenter et al., 1995). The very light values of $\delta^{18}-(-9.04 \%)$ suggest a telogenetic environment of formation for the calcite crystals. If all this is assumed, this chert was formed before the emergence of the sequence.

At the top of the section, double nodules consist of MB chert partially enveloped by Wo chert (Fig. 5b and $\mathrm{c}$ ). The attack front (megaquartz islands of advance) of the $\mathbf{M B}$ chert remains visible in the WO chert (Fig. 6e). Therefore, WO chert was formed later than $\mathrm{MB}$ chert from disselutions richer in silica because opaline minerals were precipitated. The compaction structures of host røcks reflected in both cherts are similar, which shows that both silicifications are produced by the postcompaction of the host rocks. Mørevver, the deformation of søme opaline nodules, which appear flattened in relation to the MB chert, indicates that the compaction had not been finished when the WO chert was formed. The ${ }^{18}$ isotopic cœmposition $\bullet$ the replacement waters from WO chert cannot be deduced because the opal amount is high.

\subsubsection{Source of silica}

The søurce of silica is not clear, because silice us microfossils have not been detected in the limestones or in the uncemented carbonate muds. The location of the chert nodules only in the limestones can suggest that the silica source was included only in these facies, because it is difficult to think of a general distribution -f silica from the grøundwater where the most pørøus facies have not been affected. The chalks are, in general, very appropriate host rocks for silicification because of their pørøsity/permeability (Ziljstra, 1995).

The existence of the remains of microbial films in the limestones can explain the presence of silica because such films may provide the loci for silica precipitation. Although they have not been observed, diatoms could have been associated with microbial mats. Riding (1994) and Winsborøugh (2000) point out that the diatoms appear to be of particular importance in the formation of microbial films, because of their ecølogical success and their effect on mat grøwth, stability and trapping. Differences in the grade of dissolution of the frustules, according to the diatom species, can be a hypothesis to explain the liberation of silica in different stages.

\section{Conclusions}

(1) The lower part of the Paleøgene Carbønate Unit is formed by carbonate facies that indicate low-energy lakes with low gradient ramp-type margins. Textures and composition allowed us to distinguish several sedimentary carbonate facies, which represent different lacustrine envirøments: supralittoral, eulittoral, littoral and basinal. These carbonate facies form different types of regressive sequences where calcitic and dolømitic uncemented muds are followed by bioclastic mudstones/wackestones or microbial laminated limestones. When these upper facies of the sequences are affected by subaerial exposure, palustrine limestones and dolocretes complete the shallowing upward sequences.

Carbon and oxygen stable isøtopic values for littoral (bioclastic mudstones/wackestones and micrbial laminated limestones) and basinal lacustrine sediments (uncemented carbonate muds) suggest that both types of carbonates precipitated in equilibrium with meteoric waters, isotopically light. In the palustrine carbønates, the $\delta^{13} \mathrm{C}$ data outline a strong organic contribution to the dissolved carbon reservoir, probably derived from $\mathrm{C}_{3}$ and/or $\mathrm{C}_{4}$ plant decay. These conditions do not change significantly for the successive sequences. The correlation between the $\delta^{18}$ and $\delta^{13} \mathrm{C}$ values in both littoral and basinal lacustrine carbonates may indicate precipitation from water with relatively long residence times in closed systems from a hydrological point of view, being the rechargeevaporation budget which controls the isøtopic ev॰lution of the water.

(2) Dolomitization affected only the uncemented carbonate muds and later some of the dolomites then formed were affected by a calcite cementation. The micre-rhombic crystals with poorly ordered and the nearly stoichiometric characteristics and their porøsity, similar to the calcitic muds, could indicate an early process. Dolømitic uncemented mud is probably the "end member" of an early dolømitization process overprinting an HMC mud precursor.

Since the calculated average of $\Delta^{18} 0_{\text {do1-cal for }}$ calcitic and delomitic uncemented muds is abøut $6 \%$, an early diagenetic origin for the dolomites might alse be deduced. If we assume that calcite and dolomite precipitated at normal surface temperatures, the dølømites precipitated from water was more 
enriched in heavy isotopes $\left(\delta^{18}\right.$ values from $-1.9 \%$ to $-4.1 \%$ SMOW) than the calcite $(-3.5 \%$ to $-5.8 \%$ o SMOW) due to an increase of evaporation rates.

(3) The replacement of the limestones by silica -nly occurs in littoral and eulittoral sequences, probably due the presence of microbial mats (including diatoms). Three stages of silicification during the early diagenesis and different types of chert are found. The first stage (TB chert) took place before significant burial of the carbonate depesits and the other two stages (MT chert and WO chert) were after the compaction of the limestones. Every stage of silicification was produced from porewaters of different silica supersaturation. According to the quartz textures and the presence or absence of $\bullet$ pal CT, the sølutions -f the first and third stage of silicification were richer in silica than those of the second silicification.

$\delta^{18}$ values of quartz in the TB and $\mathbf{M B}$ cherts indicate that the formation of quartz in the first and secønd silicification occurre from similar meteoric waters (from $-10 \%$ to $-8 \%$ SMOW), which are clearly lighter than the values for the calcite precipitating waters. Some cherts included in the palustrine limestones are special cases because they record more evaporated waters than those of the general stages of silicification. The isotopic composition of the waters of the third stage of silicification carmot be def ined due to the interference of important amounts of opal mixed with quartz in the composition of the Wo chert.

\section{Acknowledgements}

The research was supported by the project PB-980668-C02-01 of the Dirección General de Investigación. This paper greatly benefited from the reviews of Joumal referees, Dr. Ildefonsø Armenterøs, and Dr. Paul Wright and the careful editorial work of Dr. Bruce Sellwood. We thank them for their helpful suggestions and comments.

\section{References}

Allan, J.R., Matthews, R.K., 1982. Isotopic signatures associated with early meteoric diagenesis. Sedimentology 29, 797-817.

Alvaro, M., Capote, R., Vegas, R., 1979. Un modelo de evolución geotectónica para la Cadena Celtibérica. Acta Geol. Hisp. 14, $172-177$

Armenteros, I., Bustillo, M.A., Blanco, J.A., 1995. Pedogenic and groundwater processes in a closed Miocene basin (northern Spain). Sediment. Geol. 99, 17-36.

Arribas, M.E., 1986a. Petrología y análisis secuencial de los carbonatos lacustres del Paleógeno del sector $\mathrm{N}$ de la cuenca terciaria del Tajo. Cuad. Geol. Iber. 10, 295-334.

Arribas, M.E., 1986b. Estudio litoes ratigráfico de una unidad paleógena: sector $\mathrm{N}$ de la Cuenca del Tajo. Estud. Geol. 42, 103116.

Arribas, M.E., 1994. Paleogene of the Madrid Basin (northeast sector), Spain. In: Gierlowski-Kordesch, E., Kelts, K. (Eds.), A Global Geological Record of Lake Basins, vol. I. Cambridge Univ. Press, Madrid, pp. 255-259.

Arribas, J., Arribas, M.E., 1991. Petrographic evidence of different provenance in two alluvial fan systems (Paleogene of the northem Tajo Basin, Spain). Geol. Soc. Spec. Publ. 57, 263-271.

Arribas, M.E., Bustillo, M.A., 1985. Modelos de silicificación en los carbonatos lacustre-palustres del Paleógeno del borde NE de la Cuenca del Tajo. Bol. Geol. Min. 96, 325-343.

Arribas, M.E., Díaz-Molina, M., López-Martínez, N., Portero, J.M., 1983. El abanico aluvial paleógeno de Beleña de Sorbe (Cuenca del Tajo): facies, relaciones espaciales y evolución. X Congreso Nacional de Sedimentología, Menorca. Comunicaciones, vol. 1, pp. 34-38.

Borthwick, J., Harmon, R.S., 1982. A note regarding CIF3 as an altemative to BrF5 for oxygen isotope analysis. Geochim. Cosmochim. Acta 46, 1665-1668.

Bustillo, M.A., 2001. Cherts with moganite in continental Mg-clay deposits: an example of false Magadi-type cherts Madrid Basin, Spain. J. Sediment. Res. 71, 436-443.

Bustillo, M.A., Arribas, M.E., Pozo, M., Casas, J., 1998. Dolomitization, silicification and neoformation of clays in lacustrinepalus rine sequences (Paleogene of the Madrid Basin, NE sector, Spain). 15th International Sedimentological Congress. IAS, Alicante, Spain, pp. 219-220.

Camoin, G., Casanova, J., Rouchy, J.M., Blanc-Valleron, M.M., Deconinck, J.F., 1997. Enviromental controls on perennial and ephemeral carbonate lakes: the central palaeo-Andean Basin of Bolivia during Late Cretaceous to early Tertiary times. Sediment. Geol. 113, 1-26.

Casanova, C., Hillarie-Marcel, C., 1992. Chronology and paleohydrology of Late Quatemary high levels in the Manyara Basin (Tanzania) from isotopic data (12C, 18@, 14C U/Th) on fossil stromatolites. Quat. Res. 38, 1-22.

Chafetz, H.D., 1994. Bacterially induced precipitates of calcium carbonate and lithification of microbial mats. In: Krumbein, W., Patterson, M.D., Stal, J.L. (Eds.), Sediment Stabilization. Bibliotek und Informat Der Univ., Oldenburg, pp. 149-163.

Clayton, R.N., Mayeda, T.K., 1963. The use of bromine pentafluoride in the extraction of oxygen from oxides and silicates for isotopic analysis. Geochim. Cosmochim. Acta 27, 43-52.

Clayton, R.N., 'Neil, J., Mayeda, T.K., 1972. Oxygen isotope exchange between quartz and water. J. Geophys. Res. 77, 30573067.

Craig, H., 1957. Isotopic standards for carbon and oxygen and 
correction factors for mass-spectrome anic alysis of carbon dioxide. Geochim. Cosmochim. Acta 12, 133-149.

Craig, H., 1965. The measurement of oxygen isotope paleotemperatures. In: Tongiorgi, E. (Ed.), Stable Isotopes in Oceanographic Studies and Paleotemperatures. Consiglio Nazionale delle Richerche, Laboratorio de Geologia Nuceare, Pisa, pp. 161-182.

Craig, H., Gordon, L.I., 1965. Deuterium and oxygen-18 variations in the ocean and the marine atmosphere. In: Tongiorgi, E. (Ed.), Stable Isotopes in ceanographic Studies andPaleotemperatures. Consiglio Nazionale delle Richerche, Laboratorio de Geologia Nuceare, Pisa, pp. 9-130.

Degens, E.T., Epstein, S., 1964. Oxygen and carbon isotope ratios in coexisting calcites and dolomites from recent and ancient sediments. Geochim. Cosmochim. Acta 28, 23-44.

Epstein, S., Buchsbaum, R., Lowenstam, H.A., Urey, H., 1953. Revised carbonate-water isotopic temperature scale. Geol. Soc. Am. Bull. 64, 1315-1326.

Epstein, S., Graf, D.L., Degens, E.T., 1964. Oxygen isotope studies on the origin of dolomites. In: Craig, H. (Ed.), Isotopic in Cosmic Chemiswy. North-Holland, Amsterdam, pp. 169-180.

Eugster, H.P., Kelts, K., 1983. Lacus chemical sediments. In: Goudie, A.S., Pye, K. (Eds.), Chemical Sediments and Geomorphology, Academic Press, London, pp. 321-368.

Fontes, J.Ch., Fritz, P., Létolle, R., 1970. Composition isotopique, minèralogique et genèse des dolomies du Bassin de Paris. Geochim. Cosmochim. Acta 34, 279-294.

Freytet, P., Plaziat, J.C., 1982. Continental carbonate sedimentation and pedogenesis-late cretaceous and early tertiary of Southem France. Contrib. Sedimentol. 12, 213 pp.

Friedman, I., Gleason, J.D., 1973. Notes on the bromine pentafluoride teclinique of oxygen extraccion. J. Res. U.S. Geol. Surv. 1, $679-680$.

Fritz, P., Smith, D.G.W., 1970. The isotopic composition of secondary dolomites. Geochim. Cosmochim. Acta 34, 1161-1173.

Gasse, F., Fontes, J.C., Plaziat, J.C., Carbonel, P., Kaczmarska, I., De Deckker, P., Soulie-Marsche, I., Callot, I., Dupeuble, P.A., 1987. Biological remains, geochemis and stable isotopes for the reconsuction of environmental and hydrological changes in the Holocene lakes from North Sahara. Palaeogeogr. Palaeoclimatol. Palaeoecol. 60, 1-46.

Gerdes, G., Knumbein, W.E., Reineck, H.-E., 1994. Microbial mats as architects of sedimentary surface smuctures. In: Knumbein, W., Patterson, M.D., Stal, J.L. (Eds.), Sediment Stabilization. Bibliotek und Informat. Der Univ., Oldenburg, pp. 165-181.

Geyh, H., Merkt, J., Müller, H., 1971. Sediment, pollen and isotopopenalysen and jahreszeitlich geschichteten ablagenungen in zentralen Teil des Schleinsees. Arch. Hydrobiol. 69, 366-399.

Gierlowski-Kordesch, E., Kelts, K., 1994. Global Geological Record of Lake Basins, vol. 1. Cambridge Univ. Press, Cambridge, $427 \mathrm{pp}$.

Grigor'ev, D.P., 1965. Ontogeny of Minerals: Translated from Russian, Israel Program for Scientific Translation, Jerusalem, 250 pp.

Gunatilaka, A., 1991. Dolomite formation in coastal Al-Khiran, Kuwait Arabian Gulf-a re-examination of the sabkha model. Sediment. Geol. 72, 35-53.

Hardy, R., Tucker, M., 1988. X-ray powder diffraction of sediments.
In: Tucker, M. (Ed.), Teclıniques in Sedimentology. Blackwell, Oxford, pp. 191-228.

Hesse, R., 1990. Silica diagenesis: origin of inorganic and replacement cherts. In: Mcllreath, A., Morrow, D.W. (Eds.), Diagenesis. Geoscience of Canada, vol. 4, GAC, Canada, pp. 253-275.

Hudson, J.D., 1977. Stable isotopes and limestone lithification. J. Geol. Soc. (London) 133, 637-660.

Jones, B., Renaut, R.W., Rosen, M.R., Klyen, L., 1998. Primary siliceous rhizoliths from Loop Road hot springs, North Island, New Zealand. J. Sediment. Res. 68, 115-123.

Keith, M.L., Weber, J.N., 1964. Carbon and oxygen composition of selected limestones and fossils. Geochim. Cosmochim. Acta 28, $1787-1816$.

Kelts, K., Hsü, K.J., 1978. Freshwater carbonate sedimentation. In: Lerman, A. (Ed.), Lakes, Chemistry, Geology Physics. SpringerVerlag, Berlin, pp. 295-353.

Kolodny, Y., Epstein, S., 1976. Stable isotope geochemistry of deep-sea cherts. Geochim. Cosmochim. Acta 40, 1195-1209.

Krenmayr, H.G., 1997. Chalk and delta sediments from the last interglacial at Mondsee (Upper Austria). 18 th IAS Regional European Meeting of Sedimentology, IAS, Heidelberg, pp. 208-209.

Land, L.S., 1980. The isotopic and race element geochemis of dolomite: the state of the art. In: Zenger, D.H.O., Dunham, J.B., Ethington, R.L. (Eds.), Concepts and Models of Dolomitization. Soc. Econ. Paleont. Miner., Spec. Public., vol. 28. SEPM, Tulsa, Oklahoma, pp. 87-110.

Land, L.S., 1983. The application of stable isotopes to the studies of the origin of dolomite and to problems of diagenesis of clastic sediments. In: Arthur, M.A., Anderson, T.F. (Eds.), Stable Isotopes in Sedimentary Geology. SEPM Short Course, vol. 10, pp. 4.1-4.22.

Last, W.M., 1990. Lacus ine dolomite - an overview of modem, Holocene, and Pleistocene occurrences. Earth-Sci. Rev. 27, 221-263.

Lumsden, D.L., 1979. Discrepance between thin section and X-ray estimates of dolomite in limestone. J. Sediment. Perol. 49, 429-436.

Lumsden, D.N., Chimahusky, J.S., 1980. Relationship between dolomite nonstoichiometry and carbonate facies parameters. In: Zenger, D.H., Dunham, J.B., Ethington, R.L. (Eds.), Concepts and Models of Dolomitization. Soc. Econ. Paleont. Miner., Spec. Public., vol. 28. SEPM, Tulsa, Oklahoma, pp. 123-137.

Maliva, R., Siever, R., 1988. Pre-Cenozoic nodular cherts: evidence for opal-CT precursors and direct quartz replacement. Am. J. Sci. $288,799-809$.

Matheney, R.K., Knauth, L.P., 1993. New isotopic temperature estimates for early silica diagenesis in bedded cherts. Geology 21 , $519-522$.

Matthews, A., Katz, A., 1977. Oxygen isotope fractionation during the dolomitization of calcium carbonate. Geochim. Cosmochim. Act 41, 1431-1438.

McBride, E.F., Abdel-Wahab, A., El-Younsy, A.M., 1999. Origin of spheroidal chert nodules, Drunka Formation (Lower Eocene), Egypt. Sedimentology 46, 733-755.

McCrea, J.M., 1950. On the isotopic chemistry of carbonates and a paleotemperature scale. J. Chem. Phys. 18, 849-857.

McKenzie, J.A., 1981. Holocene dolomitization of calcium carbo- 
nate sediments from the coastal sabkhas of Abu Dhabi, U.A.E.: a stable isotope study. J. Geol. 89, 185-198.

Murata, K.J., Norman, M.B., 1976. An index of crystallinity for quartz. Am. J. Sci. 276, 1120-1130.

Müller, G., Wagner, F., 1978. Holocene carbonate evolution of Lake Balaton (Hungary): a response to climate and the input of man. In: Matter, A., Tucker, M.E. (Eds.), Modem and Ancient Lake Sediments. Spec. Publ. Int. Ass. Sedimentology, vol. 2. IAS, Oxford, pp. 57-81.

Müller, G., Iron, G., Försmer, U., 1972. Formation and diagenesis of inorganic $\mathrm{Ca}-\mathrm{Mg}$ carbonates in the lacustrine environment. Naturwissenschaften 59, 158-164.

Northrop, D.A., Clayton, R.N., 1966. Axygen isotope fractionation in systems containing dolomite. J. Geol. 74, 174-196.

-Neil, J., Epstein, S., 1966. Oxygen isotope fractionation in the system dolomite-calcite-carbon dioxide. Science 152, 198201.

Platt, N.H., Wright, V.P., 1991. Lacus carbonates: facies models, facies distributions and hydrocarbon aspects. Spec. Publ. Int. Assoc. Sedimentol. 13, 57-74.

Riding, R.E., 1994. Stromatolite survival and change: the signifcance of Shark Bay and Lee Stocking Island subtidal colunms. In: Knumbein, W.E., Paterson, D.M., Stal, L.J (Eds.), Biostabilization of Sediments. Bibliotheks und Informationssystem der Universitat, Oldenburg, pp. 183-202.

Salomons, W., Mook, W.G., 1976. Isotope geochemis of carbonate dissolution and reprecipitation in soils. Soil Sci. 122, 1524.

Salomons, W., Goudie, A., Mook, W.G., 1978. Isotopic composition of calcrete deposits from Europe, Africa and India. Earth Surf. Processes 3, 43-57.

Spiker, E.C., 1980. Carbon isotopes as indicators of the source and fate of carbon in rivers and estuaries, In: Flux of rganic Carbon by Rivers to the Cceans, U.S. Dept. of Energy, effice of Energy Research, CONF.-8009140, UC-11, pp. 75-108.

Talbot, M.R., 1990. A review of the palaeohydrological interpretation of carbon and oxygen isotopic ratios in primary lacuswine carbonates. Chem. Geol. 80, 261-279.

Talbot, M.R., Kelts, K., 1990. Paleolinmological signatures from carbon and oxygen isotopic ratios in carbonates from organic carbon-rich lacus ine sediments. In: Katz, B.J. (Ed.), Lacus ine Basin Exploration-Case Studies and Modem Analogs. Mem. Am. Assoc. Pet. Geol., vol. 50, AAPG, Tulsa, Okla, pp. 99112.

Talma, A.S., Netterberg, F., 1983. Stable isotopic abundances in calcretes. In: Wilson, R.C.L. (Ed.), Residual Deposits: Surface Related Weathering Processes and Materials. Spec. Publ. Geol. Soc. London, vol. 11, Geological Society, London, pp. 221 - 233.

Tucker, M.E., Wright, V.P., 1990. Carbonate Sedimentology. Blackwell, Oxford, $482 \mathrm{pp}$.

Winsborough, B.M., 2000. Diatoms and benthic microbial carbonates. In: Riding, R.E., Stanley, M.A. (Eds.), Microbial Sediments. Springer-Verlag, Berlin, pp. 76-83.

Wright, V.P., Alonso-Zarza, A., Sanz, M.E., Calvo, J.P., 1997. Diagenesis of late Miocene micritic lacus carne carbonates, Madrid Basin, Spain. Sediment. Geol. 114, 81-95.

Yébenes, A., de la Peña, J.A., Ordoñez, S., 1973. Sedimentos dolomíticos para-actuales: la "Tierra Blanca" de la Roda (Albacete). Estud. Geol. 29, 343-349.

Ziljstra, H., 1995. The sedimentology of chalk. Lecture Notes in Earth Sciences. Springer-Verlag, Berlin.

Zuffa, G.G., 1980. Hybrid arenites: their composition and classifcation. J. Sediment. Perol. 50, 21-29. 